\title{
並列分散対話型遺伝的アルゴリズムを用いた合意 形成システムの有効性
}

\section{Validity of the Consensus Building System using a Parallel Dis- tributed Interactive Genetic Algorithm}

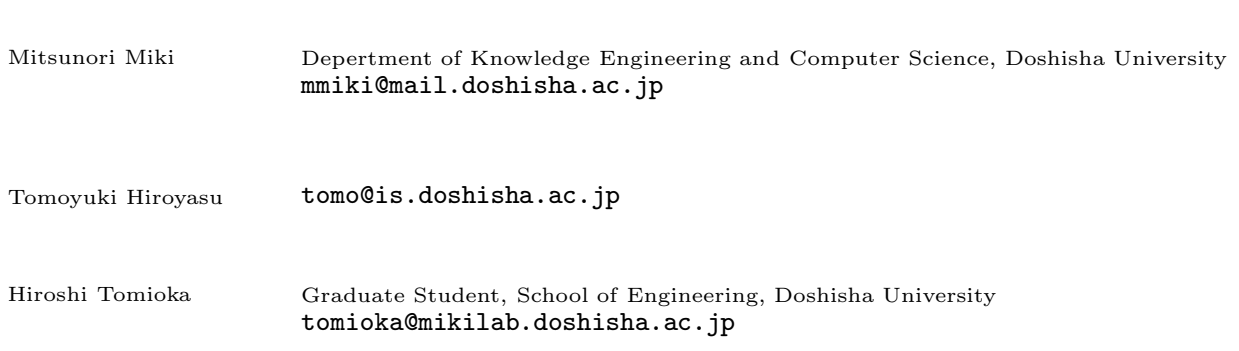

keywords: parallel processing, interactive evolutionary computation, genetic algorithm, sensibility, consensus building

\section{Summary}

We propose a parallel distributed interactive genetic algorithm(PDIGA) as a new design collaboration method. PDIGA uses an IGA and a parallel distributed genetic algorithm, which combines several IGA systems, and it has a scheme that best ones among the design solutions based on the subjective evaluation of each user are shared among users for every generation. A collaboration system using PDIGA is developed to make good design solutions among several people at difference locations. To verify a validity of the PDIGA system, we conducted experiments for comparing IGA and PDIGA. In particular, we examined each user's evaluation to the final design, compared the averages of the individual evaluation value, and examined the similarity of the design solution. These showed that the collaboration system using PDIGA become a consensus building system, and users' design solutions are unified in a group.

\section{1.は じめに}

近年，商品設計において，工学的尺度に加えて意匠性 などの付加価値を高める感性的尺度の重要性が高まって いる. 乥れに伴い, 感性に対する工学的な研究が注目され ている .これまで人間の感性に合うデザインやものをシ ステムで設計する場合, 人間の評価系の代替モデルを作 成し, 最適化システムに組み込むという手法がとられて きた．しかし，人間の感性をモデル化することは困難であ るため，従来の最適化手法を用いて最適化を行うことは 容易ではない，乥こで，人間兴のものを最適化系に組み込 み, 本人の評価に基づいて最適化を行う方法が考えられ る.このように，人間と機械との相互作用によって主観的 評価値に基づく最適化を行う手法のうち，進化的計算を 用いたものを対話型進化計算 (Interactive Evolutionary Computation : IEC) という [高木 00].

対話型進化計算法における代表的な手法のうち，生 物の適応進化を模倣する遺伝的アルゴリズム (Genetic Algrithm：GA) を用いて最適解を導き出す対話型遺伝
的アルゴリズム (Interactive Genetic Algorithm:IGA) がある [高木 00]. GA は生物の適応進化を工学的にモデ ル化したアルゴリズムである [Goldberg 89]．GA にお いて 1 つの設計解は個体と呼ばれ, 複数の個体からなる 母集団が，個体の交叉，突然変異，および選択によって 変化し, 多くの世代を経た後に最適解が得られる．また， IGA とは人間が持つ印象，好み, 見やすさといった人間 の感性を評価関数とした GA であり，人間の主観的評価 值に基づいて最適化を行う手法である.

IGA は , 1 人の人間の感性に基づいて設計を行うこと に対して有効であり，これまで多くの研究が行われてき た [青木 98, 和田 03, Masataka 03, 中洲 03, 久保 00]. しかしながら，これらは全て 1 人の人間の評価に基づい て設計を行うものであり，複数の人間の感性を基に，共 同で単一のものをデザインする場合には用いることがで きない .ここでは, IGA を複数の人間で用いることが可 能な手法を提案し，これを用いたコラボレーションシス テムの可能性を検証する . 


\section{2. 合 意 形 成}

意思決定者が複数存在する場合，例えば企業における 経営方針の決定などの場合では，異なった価値基準を持 つ意思決定者の意見を完全に一致させるということは多 くの場合，容易ではない，光のため，これら複数の人間 で意見の集約を図るために合意形成を行う必要がある．

合意形成とは，意思決定者間で納得できる形で合意を 図り，集団での意思決定を行うことである.近年ではこの ような集団意思決定のための合意形成支援をコンピュー タを用いて行うという研究が盛んである.例えば, 評価 基準が異なった人間同士での合意形成支援 [加藤 98]や， 各意思決定者の立場や視点を共有し，互いの意見が衝突 する部分については説得あるいは妥協を促すようにしな がら合意形成を行う方法の提案 [加藤 97] , コンセンサス に基づくグループ意思決定支援 [渡部 92]，操作者同士の 概念の相違を理解し, 互いの合意を促すシステムの研究 [角 02] などがある.これらはコンピュータを用いて代替 案の評価を行い，互いが重要視する項目を視覚化し，光 れらの不一致度を見せることで操作者間での妥協を图る ことを促す，あるいは意見や意向を抽出し，合意形成を 行うというものである。しかしながら，これらは合意形 成を行うという意思のもとで用いられており，互いに妥 協しようとする意識が働くことになる．このことは，妥 協する意思が働かなければ，合意形成ができないと考え ることができる

本稿て提案する手法は, IGA を用いて操作者自身の感 性を反映しながらも，同時に他人の感性を反映させるこ とができるため，互いに妥協するという意識なく自然な 合意形成が可能になる．つまり，これまでの合意形成支 援の手法とは異なった新たなアプローチになるといえる .

\section{3. 対話型遺伝的アルゴリズム}

IGA は GA による探索アルゴリズム中にある個体の適 合度評価を人間が行う．IGA では，GA における遺伝的 操作と, 人間の評価という人為的な操作の両方によって 解の探索を行うため, 人の感性という複雑な構造の解析 に，より適していると言われている[高木 00] .

IGA のアルゴリズムを図 1 に示す .

(1) 個体群の初期化 (Initialization)

GA と同樣に個体群の初期化を行う .

(2) 提示 (Display Solutions)

IGA において, 評価を行うのは操作者であるため， 個体の提示が必要である .

(3) 評価 (Evaluation)

各個体について評価を行う．GAにおいては，適合 度関数により適合度か計算されたが, IGA において は，操作者が主観評価に基づいて個体を評価し，適 合度を与える。評価方法については，5段階評価の
ようなある程度荒い評価のほうが操作者にとって評 価しやすいという提案がなされている [H.Oya 98] .

(4) 終了判定 (Terminal Condition)

IGA において探索の終了は操作者が判断する.求 められるものが得られたのであれば IGA を終了し， 得られていないのであれば, 再ひ評価, 選択, 交叉， 突然変異といった遺伝的操作を繰り返す．

(5) 選択 (Selection)

GA と同樣に適合度に依存した一定の規則で個体 の選択を行う .

(6) 交叉 (Clossover)

GA と同樣に，選択個体に対して交叉を行う.

(7) 突然変異 (Mutation)

個体の多樣性を維持するため，個体の解の一部を ランダムに変化させる .

図 1 から分かるように, IGA のアルゴリズムは GA と似ている.IGA は GA と同樣に，個体に対して選択， 交叉, 突然変異を経て新しい個体を生成する. IGA と GA との大きな相違は個体の評価方法と終了条件にある . IGA において , 人間は心理空間上のターゲットとシステ ムの出力との間の距離に応じて個体を評価し，GA は光 の心理空間上の距離尺度を評価值として特徵パラメータ 空間を探索する IGA では, 人間か評価値を与えるので GAのように評価関数が一定ではない. 光のため，心理空 間上の好みと評価值が摇らぐ可能性がある．ただし，人 間の評価の摇らぎに基づいてシミュレーションで収束性 を調べた結果でもほとんど影響がないと報告されている [H.Oya 98, 高木 96] .

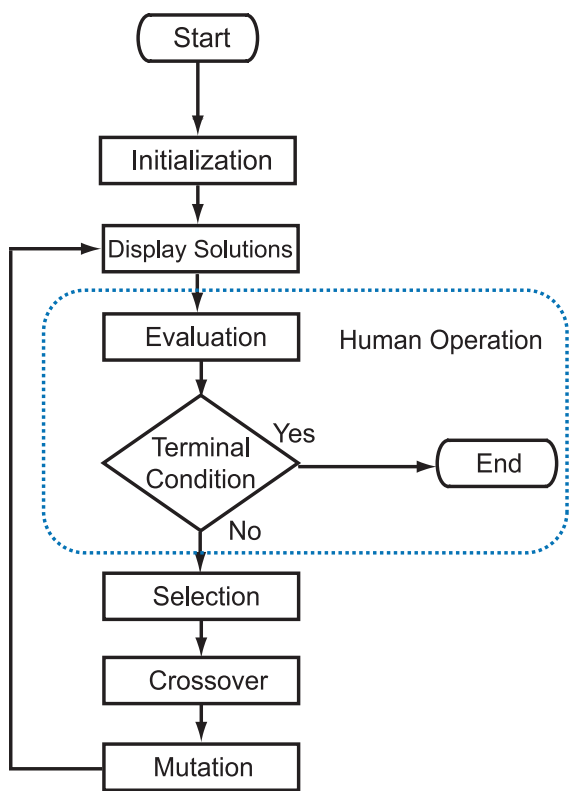

図 1 IGA のアルゴリズム 


\section{4. 並列分散対話型遺伝的アルゴリズム}

\section{$4 \cdot 1$ 並列分散対話型遺伝的アルゴリズムの提案}

並列分散対話型遺伝的アルゴリズム (Parallel Distributed Interactive Genetic Algorithm:PDIGA) は, 並列分散 遺伝的アルゴリズム (Parallel Distributed Genetic Algorithm : PDGA) [三木 01] の考え方を適用し，IGA を 並列分散モデルに拡張する手法である . 产の概念図を図 2 に示す．ここでMigration とは，移住と呼ばれる設計解 の交換を意味する . IGA の並列分散モデルとは, ネット ワークを用いて複数のコンピュータを繁ぎ, 弚れ光れのコ ンピュータ上でIGA を行う仕組みである . 光して, 各世 代ごとに各操作者が良いと判断した設計解をコンピュー タ間で通信することにより，互いの設計解を IGA 処理に 組み込むことができる．

PDIGA では GA における遺伝的操作が行われた後， 各操作者がェリートとして選択した解を互いに交換し， 次世代で提示される解候補に組み込まれる．この移住し てきた個体が親個体として採用されることによって，次 世代では他操作者の感性を反映した新たな解が生成され ることになる．この操作か数世代に渡って繰り返し行わ れることにより，各操作者の感性を反映した設計解の作 成が可能となる．

\section{$4 \cdot 2$ コラボレーションツールとしての PDIGA}

移住してきた個体を他人が良いと判断すれば高い評価 がつけられ，光の個体は進化に影響を与える個体となる． このように各操作者からの移住個体が解探索に影響を及 ぼすことによって, 集団内で自然なコラボレーションが 行われ，互いに妥協するという意識が働くことなく合意 形成することが期待できる．乥こで本稿では，PDIGA を用いたシステムによって合意形成することが可能であ るかを検証する . 検証のために構築したシステムと命の 目的について次章で記述する.

\section{5. 検証用システム}

\section{$5 \cdot 1$ 合意形成の検証}

本研究における評価実験を行うために「服装カラーコー ディネート支援システム」を構築した . 本システムの目 的は, 操作者が与えられたコンセプトに基づいて提示さ れた各デザインを評価していくことで, 最終的にコンセ

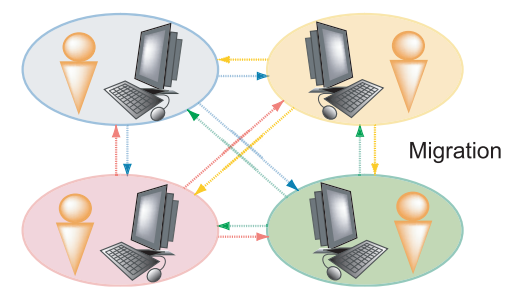

図 2 PDIGA の概念図
プトに合ったデザインを作成することである .ここでは， PDIGA を用いたシステムで合意形成を行えるかを検証 するために , 以下のようなコンセプトおよひ想定を設定 した .

・コンセプト

「冬の雪の中を歩く恋人たち」

- 想定

「操作者一人ひとりは服屋の店員である .今回 , 上 記のコンセプトに基づいて , 店のショーウィンドウ に飾るカップルの服装を 1 組決めることとなった . 光こで, グループのメンバーでデザイン作成を行っ てもらう.

このような想定のもと，複数の操作者によってコラボ レーションを行いながら解の生成や進化が行えるかどう かを検証する .

\section{$5 \cdot 2$ 服装カラーコーディネート支援システム}

本システムでは, 図 3 に示すように男性のジャケット， パンツ, 女性のジャケット, インナー , スカートの計 5 ア イテムの配色を変更することで , 最適なカラーコーディ ネートを作成する . 各設計変数における色は Hue (色相) \&Tone (色調) と呼ばれる色データの有彩色 120 色と した . 色相とは赤, 青 , 黄などの色みの変化を, 色調と は明暗, 濃淡, 派手, 地味などの色の調子を意味する . Hue\&Tone とは，無限に広がる色に対してなるべく単純 で理解しやすい有彩色 120 色と無彩色 10 色に分類・整 理したものである [小林 00] .

操作者には図 4 に示すように個体数を 12 とする画面 が提示され，操作者は各デザインに対して与えられたコ ンセプトに基づいて 5 段階で評価を行う. 光して，12 個 体のうちで最もコンセプトにあっていると思うものをエ リートとして選択する．この操作を 10 世代繰り返し，10 世代目で選択したエリートが最終的なデザインとなる .

\section{$5 \cdot 3$ システムの詳細}

\section{$\S 1$ 実数值遺伝的アルゴリズム}

カラーパターンは色相および色調か漓倠散値で表現され ている．しかし，2次元の設計空間において 2 つの色を結 んだ直線上の色は光れ光れの中間的なカラーパターンと なる．このため，GA 処理において遺伝子型空間では連 続値を用い，表現型空間では弚れらの值を離散化して用

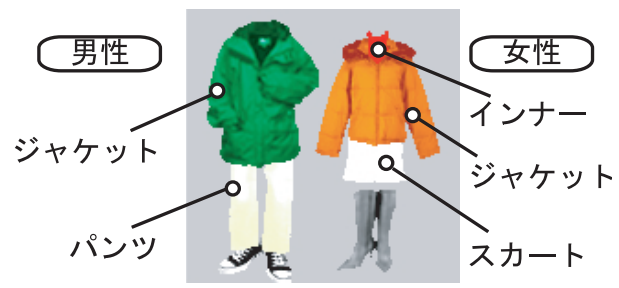

図 3 構築したシステムにおける設計変数 


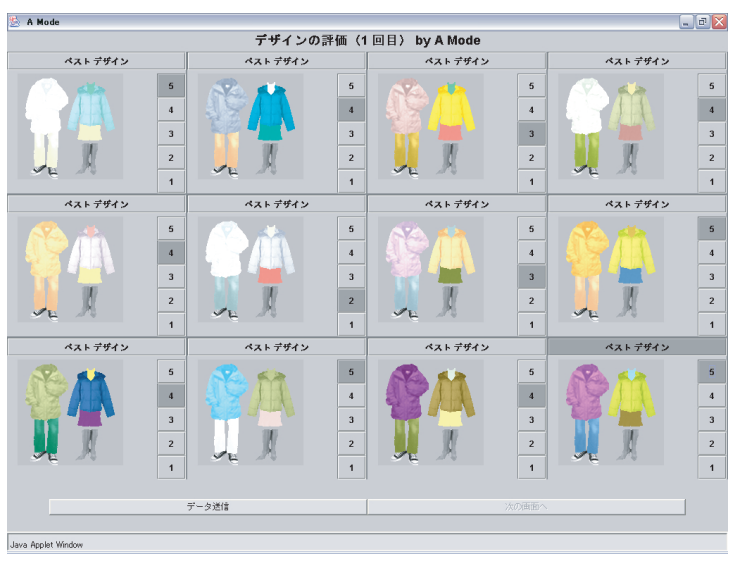

図 4 システムのインタフェース

いた . 手法としては , 表現型空間における親個体の近傍 に子個体を生成する方法である実数值 GA (Real-coded GA）を用いた . 実数値 GA は探索対象の表現型をコード 化せず, 表現型の数值谷のものを用いて交叉, 突然変異 を行うアルゴリズムである [小野 99] .交叉法には UNDX を用いた。

\section{$\S 2$ 突然変異個体と移住個体}

主観婛価実験のため，移住のある PDIGA システムと 移住のない PDIGA システム (以下 IGA システムと呼 ぶ）の 2 つのシステムを用いた，弚れ光れのシステムで は個体数 12 のうち，7つの個体が各サブ母集団におけ る突然変異および交叉によって生成される進化的な個体 であり，残りの5つの個体は，PDIGA システムでは他 のサブ母集団からの移住個体であり，IGA システムでは すべての設計変数を乱数で決定した完全な突然変異個体 とした。

移住個体を5つにした理由はPDIGA システムを用い た実験では1グループ6名で行うためである .このため， IGA システムにおいても完全な突然変異個体の数を同数 とした .これにより，移住個体と完全な突然変異個体の 差により合意形成の相違が明らかとなる．なお，どちら のシステムにおいても各サブ母集団内で行う突然変異率 は各設計変数に関して 0.2 とし, 光の突然変異は次に示 すように設計変数にわずかの変更を与えるものとした . これにより7つの進化的な個体は主として交叉により進 化し，5つの移住個体もしくは完全な突然変異個体は各 サブ母集団で進化している個体群とはまったく異なる設 計変数を持つ個体として操作者に提示されることになる． 突然変異個体の生成および移住個体は以下のように設定 した。

\section{- 突然变異}

各サブ母集団の中で行う突然変異は, Hue\&Tone における 120 色の設計空間において図 5 のように親 個体の近傍 $5 \times 5$ の中から一樣乱数を用いて生成す る.このため, この突然変異は設計変数にわずかの 変化をもたらす.なお，元の設計変数が図 5 の周辺

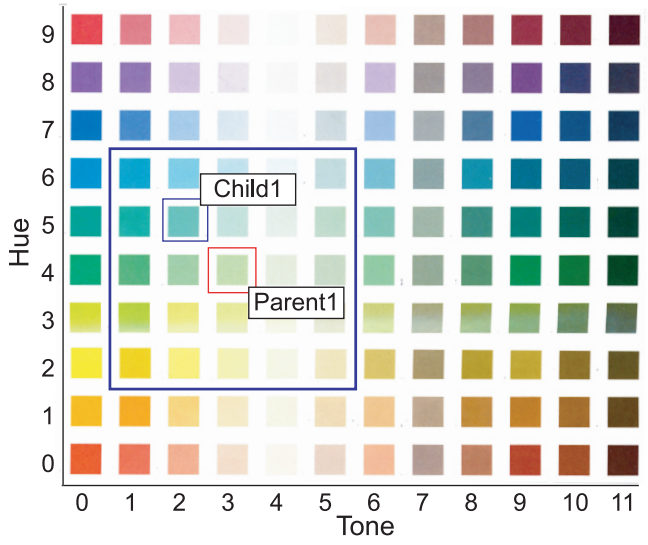

図 5 突然変異による色の変化

部分に存在する場合には図 5 の設計変数空間は上下 左右に繰り返して現れるものとして取り扱った .

一方，IGA システムにおける5つの完全な突然 変異個体は全設計変数をすべて乱数で決めたもので ある

・移住個体

移住個体は各操作者が各世代ごとに選んだエリー 卜解とする．移住は 2 世代目から毎世代行われ，表 示画面上では個体群となる 12 個体の中でランダム に配置されるので, 操作者にはどれか移住個体かは 分からない。

\section{6. 主 観 評 価 実 験}

\section{$6 \cdot 1$ 実 験 概 要}

主観評価実験とは各操作者の主観的判断によっていく つかの事物を評価する実験方法である．本実験では，各 操作者が IGA システムと PDIGA システムの 2 つのシ ステムを操作し，作成したデザインに対して比較評価を 行う. 操作者数は延べ 72 人であり， 6 人を 1 グループと する A〜L の計 12 グループで実験を行った . 操作者は 同志社大学および同志社女子大学の学生 (20 歳前後の男 女) である . 各操作者は各大学の実験室に分かれてイン ターネットを通じて実験を行う。

各操作者は, 提示された教示に従って 2 つのシステム (IGA システム , PDIGA システム) をシステム A , シス テム B として順に操作し，用意されたアンケートに回答 する.なお，操作者にはどちらが IGA システム, PDIGA システムであるか伝えない . また ，操作順序によるシス テムの評価の優越をなくすために $\mathrm{A} \sim \mathrm{F}$ の 6 グループ は IGA システム - PDIGA システムの順に , G〜L の 6 グループは PDIGA システム - IGA システムの順にシ ステムを操作するようにした .

各操作者は， $5 \cdot 1$ 節で記述したコンセプトにどの程度 合っているかをもとに，すべてのデザインを 5 段階で評 価していく . システム側では各世代ごとに同期をとり， 6 


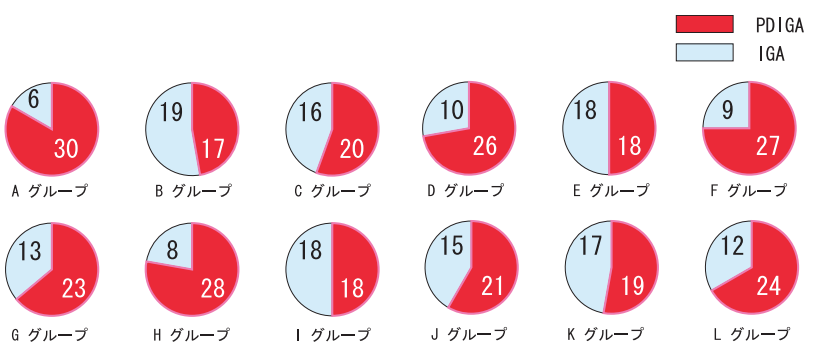

図 6 上位 6 個体のシステム別個数

人の操作者の解探索世代は同一となるようにしている . 実験終了後, 2 つのシステムで各操作者が最後に選択し た計 12 個のデザインが示される .

本実験で检証を行ったのは，以下の 4 つ項目である .

(1) デザインの検証

実験後，2つのシステムで作成したグループ全員 のデザイン 12 個を，コンセプトに合っていると思う 順に 1〜12 位まで順位をつけてもらった . この順位 について IGA システムと PDIGA システムで比較 する .

(2) 個体評価值の検証

IGA システムによって提示された個体と PDIGA システムによって提示された全個体のうち，6〜10 世代の各世代ごとの 12 個体中上位 6 個体に対する 評価値を比較する。

（3）設計解における類似性の検証

IGA システムおよびPDIGA システムて提示され たデザインについて設計解の Hue と Tone の分散を 比較し，世代を追うごとに分散がどのように変化す るかを検証する．

（4）同一初期個体による設計解の検証

PDIGA システムにおいて初期個体を指定した場 合に作成されたデザインについて , グループごとに 比較を行う．これにより，作成されるデザインが初 期個体に依存するか否かを検証する .

\section{$6 \cdot 2$ 実 験 結 果}

\section{$\S 1$ デザインの検証}

IGA システム, PDIGA システムで作成されたデザイン のうち, 各操作者に上位 6 位までに選ばれた個数をグルー プ別に集計したものを図 6 に示す .これより, PDIGA システムで作成したデザインには IGA システムで作成 したデザインより，6 位以上の順位が付けられる頻度が 高いことが分かる．

\section{$\S 2$ 個体評価値の検証}

IGA システム , PDIGA システムによって提示された デザインに対する評価値の平均をグループごとに示した ものが図 7 である.グラフの縦軸が評価値の平均 , 横軸 がグループを示す．

個体評価値の平均は, どのグループにおいても IGA シ
表 1 IGA システム, PDIGA システムでの個体評価値

\begin{tabular}{|l|r|r|}
\hline & IGA & PDIGA \\
\hline データ数 & 2160 & 2160 \\
\hline 平均値 & 3.02 & 3.32 \\
\hline 標準偏差 & 1.11 & 1.10 \\
\hline
\end{tabular}

ステムより PDIGA システムの方が高いことが分かった .

また，IGA，PDIGA の両システムにおける個体評価 值のデータについて, システム別に要約した結果を表 1 に示す.このデータを元に $\mathrm{t}$ 検定 [南風 02] を行ったとこ ろ，有意水準 0.05 の両側検定において IGA と PDIGA の評価値に有意な差があることが分かった .

\section{$\S 3$ 設計解における類似性の検証}

IGA システムと PDIGA システムの比較実験におけ る各グループの設計解を各設計変数に分解し, 各設計変 数をさらにHue と Toneに分解し, 光れ光れの分散を算 出した . 产の結果を图 8 に示す.設計解における分散は, Hue およびTone の值ごとの分散を設計変数の数で平均 したものである.グラフは縦軸が設計解における分散を， 横軸が世代数を示している.

設計解における分散は，多くのグループで PDIGA シ ステムの方が IGA システムより小さい值を取っている ことが分かる．またPDIGA システムで作成した設計解 の分散は，世代を追うごとに小さくなる傾向があること が分かる．つまりPDIGA システムで作成したデザイン は，世代を追うごとにグループ内で類似していくことが 分かる.

\section{$\S 4$ 同一初期個体による設計解の検証}

同一初期個体で実験を行った $\mathrm{D} \cdot \mathrm{E} \cdot \mathrm{F} \cdot \mathrm{J} \cdot \mathrm{K} \cdot \mathrm{L}$ グ ループのうち, 顕著な違いの見える D グループと J グ ループの設計解の履歴を図 9 と図 10 に示す.

また , D グループと J グループの PDIGA システムで 作成した最終的なデザインを图 11 に示す．

图 9 , 图 10 の 1 世代目のデザインをみると操作者によ りエリート個体として選択したデザインが異なっている． つまり各操作者では評価関数が異なっていることが分か る.しかし世代を追うごとにグループ内のデザインは類 似する傾向にあり，弚の結果図 11 に示すように，D グ

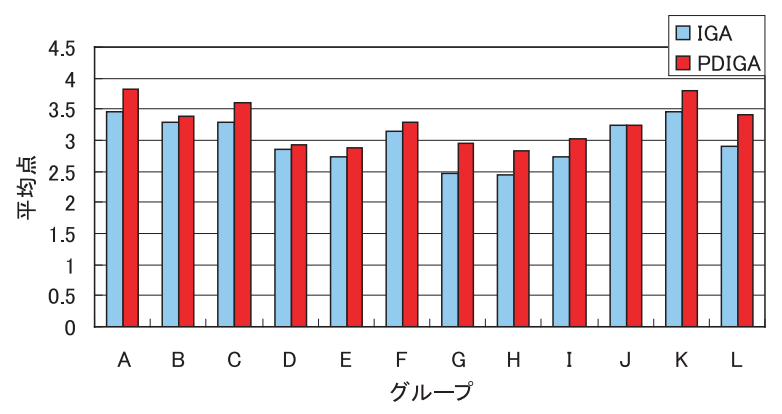

図 7 各グループにおける個体評価值平均 

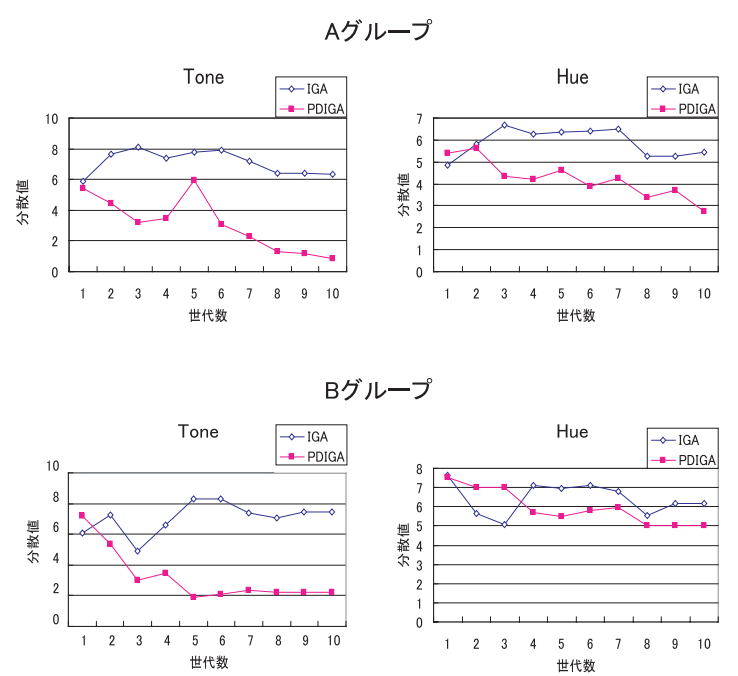

Bグループ
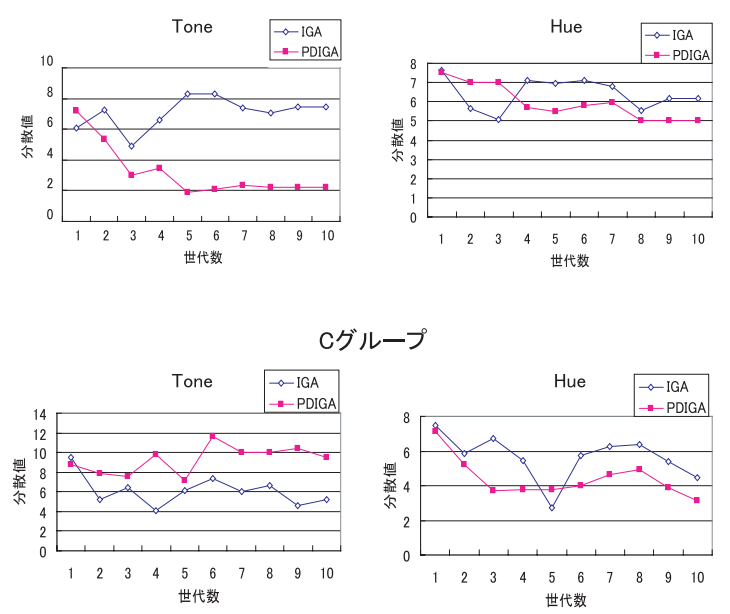

Cグループ

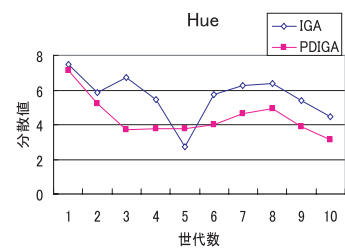

Dグループ
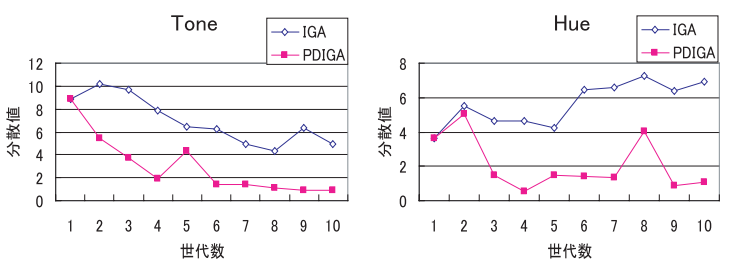

Eグループ
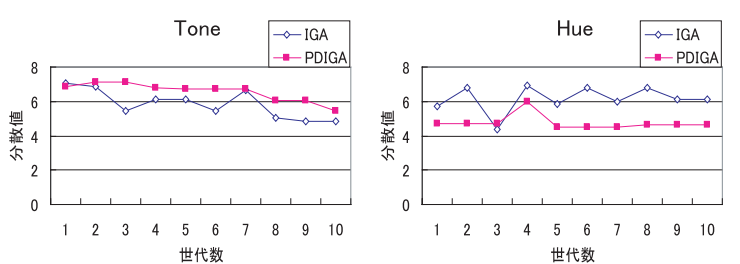

Fグループ
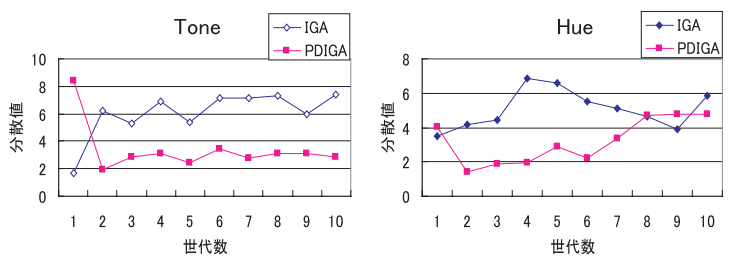
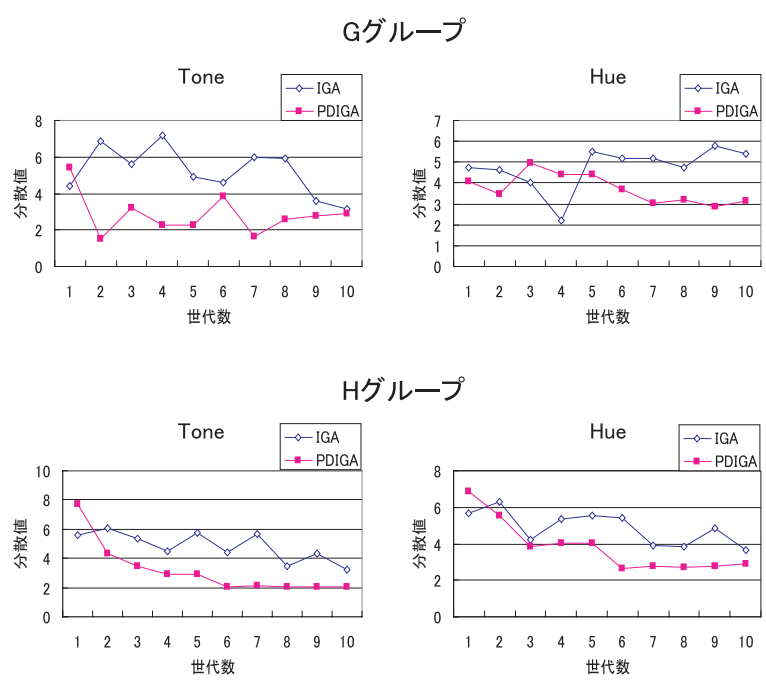

I グループ

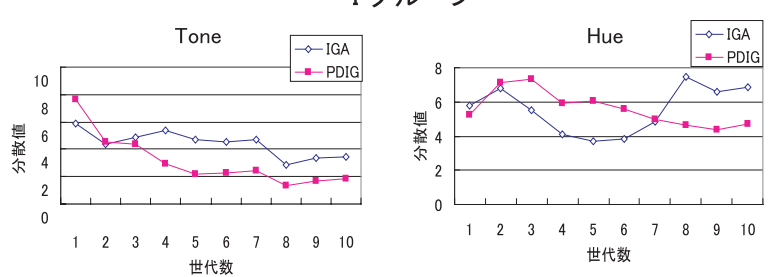

世代数

Jグループ
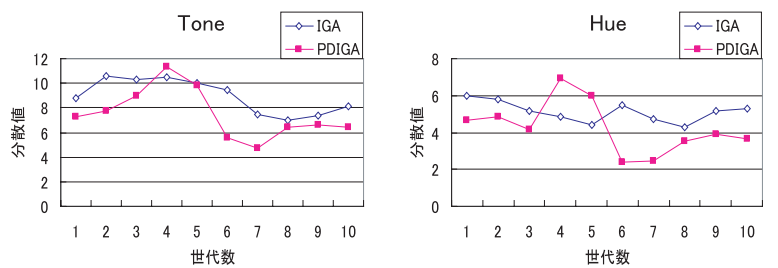

Kグループ
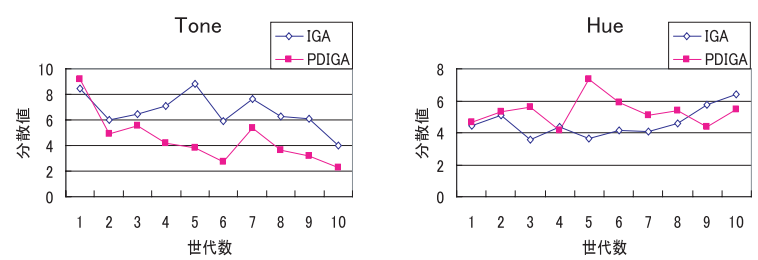

டグループ
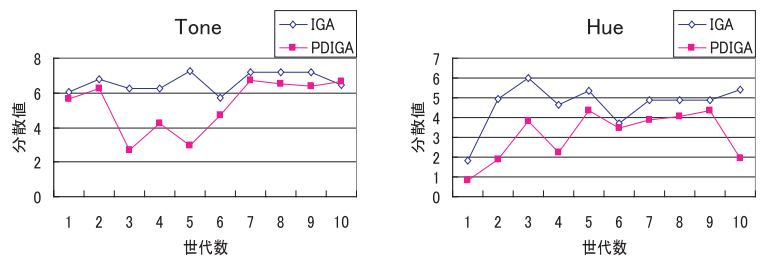

図 8 全 12 グループにおける設計解の分散 


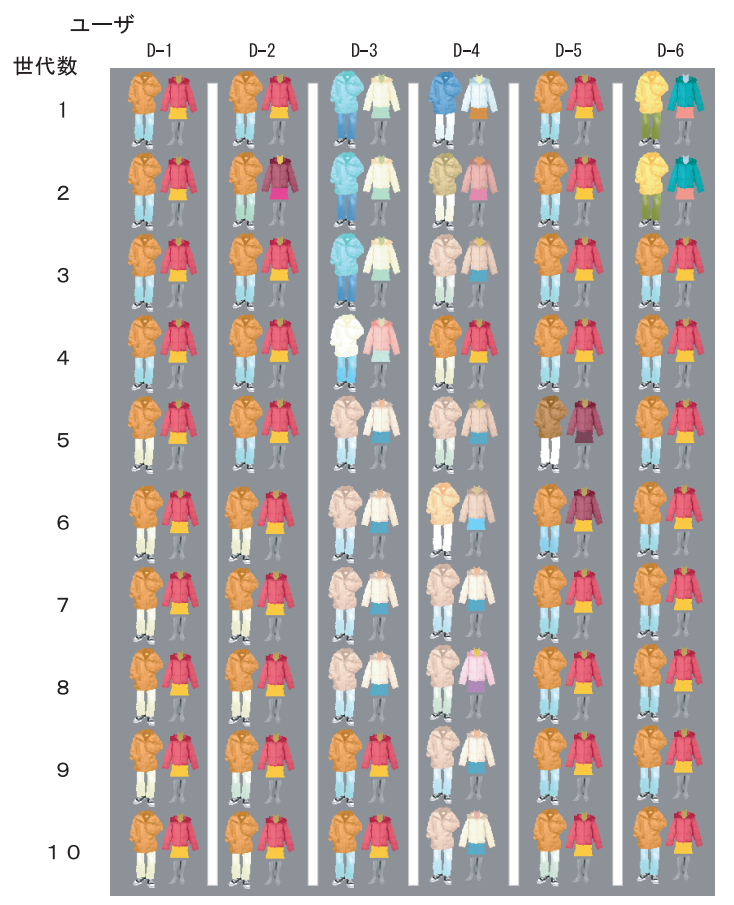

図 9 D グループのエリート個体の履歴

ループは暖色系に , J グループは寒色系にと異なったデ ザインに収束している.また図 9 , 図 10 から，同一初期 個体であってもグループにより異なったデザインの作成 が行われていることが分かる.

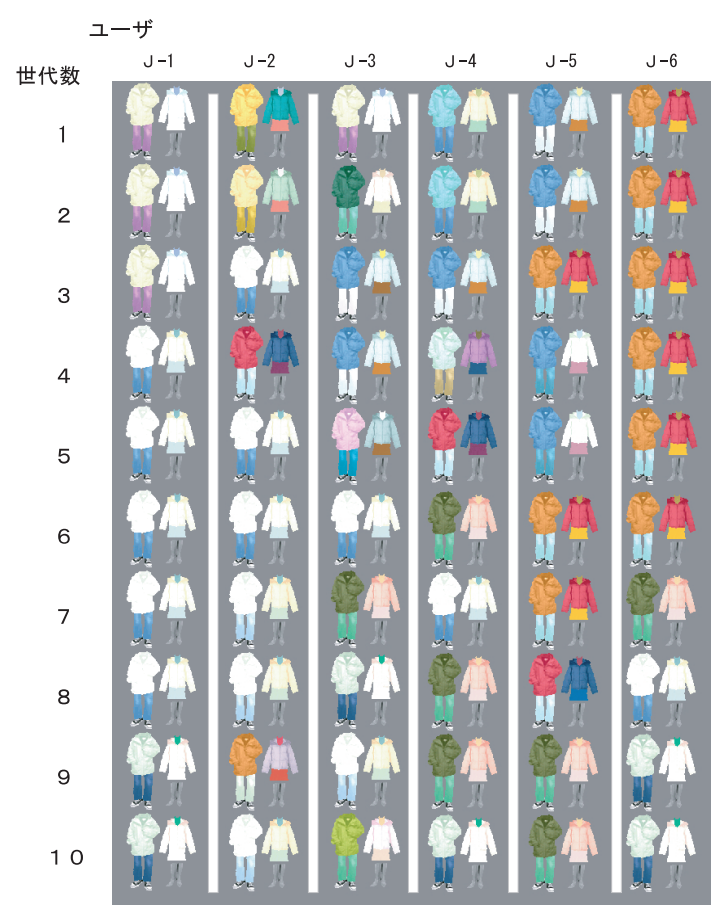

図 $10 \mathrm{~J}$ グループのエリート個体の履歴
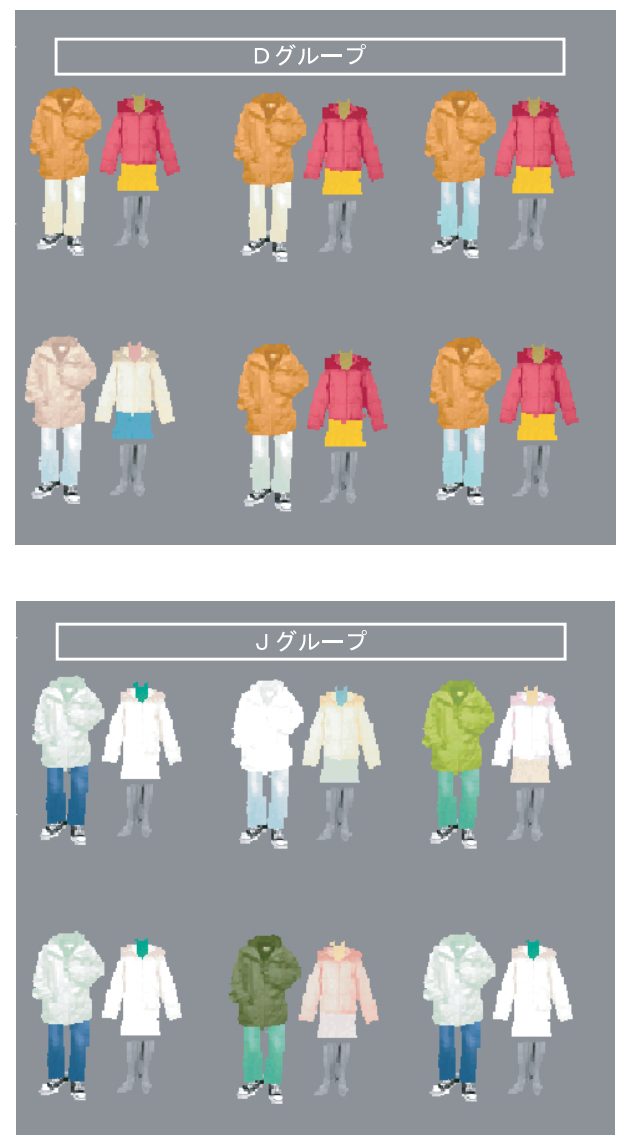

図 11 D グループと J グループの PDIGA システムで作成した デザイン

\section{$6 \cdot 3$ 考察}

\section{$\S 1$ デザインの検証}

図 6 より，PDIGA システムで作成したデザインはグ ループ内の他の操作者から見ても高く評価されることが 分かる.これは, PDIGA システムで作成したデザイン は, 移住した他の操作者の設計解が高く評価されて親個 体として選択されることで，他操作者にも高く評価され る解が生成されたためと考えられる .

\section{$\S 2$ 個体評価値の検証}

図 7 およひ検定の結果より，個体評価値の平均はPDIGA の方が高い結果となった .このことから PDIGA システ ムは , IGA システムよりコンセプトに合ったデザインを 提示していることが分かる.これは, PDIGA システムの それ光れのエリート個体を移住個体として移住させ，光 れが交叉に組み込まれることでグループ全体に良い作用 をもたらし，IGA の突然変異個体よりコンセプトに合っ た個体を生成し提示していると考えられる．

\section{$\S 3$ 設計解における類似性の検証}

グループ内のデザインの類似性がみられた理由として は，他の操作者が作成したデザインである移住個体を高 く評価することで，产の移住個体に影響を受け，各個人 の評価関数か類似したものに変化したと考えられる．し かし，弚の傾向の見られないグループもあった . これは， 
移住個体に影響を受けなかった操作者がグループ内に多 かったためと考えられる .

\section{$\S 4$ 同一初期個体による設計解の検証}

同一初期個体であってもグループにより異なったデザ インに収束することは多かった .このことから，PDIGA システムにおけるデザインの類似性は, 初期個体ではなく グループを形成する操作者に依存していると考えられる．

\section{7. ま と め}

本実験では，PDIGA システムの合意形成システムと しての可能性を探るため, グループレベルでの設計解に 対する評価の検証，個体評価値の検証，設計解の類似性 の検証 ，およびPDIGA システムにおける初期個体の影 響の検証を行った．光の結果，PDIGA システムで作成 したデザインはグループ内で高く評価されること，また， PDIGA システムは個体評価値の平均が高く，どのグルー プでもよりコンセプトに合ったデザインを提示している ことから，PDIGA システムはグループ全体で高い評価 を得られる設計解を作成できることが分かった .さらに 各グループにおける設計解の分散から，PDIGA システ ムではグループ内のデザインが類似する傾向があること も分かった .一方, PDIGA システムにおける初期個体の 影響は小さく , グループ内でのデザインの類似はグルー プを形成する操作者に依存していることが分かった .こ れらのことから，PDIGA システムでは設計解がグルー プ内で統合化の方向に向かうため，合意形成システムと 成り得るといえる。

\section{謝辞}

本研究を行うにあたり，実験にこ協力をいただきまし た同志社女子大学 学芸学部情報メディア学科 和氣早苗 助教授および和氣ゼミの学生の方々に感謝いたします．

\section{$\diamond$ 参 考 文 献 $\diamond$}

[Goldberg 89] Goldberg, D.: Genetic Algorithms in Search Optimization and Machine Leaning, Addison Wesley, Reading,Mass (1989)

[H.Oya 98] H.Oya, M., K.Osaki: An input method using discrete fitness values for interactive GA, J.of Inteligent and Fuzzy Systems, Vol. 6, No. 1, pp. 131-145 (1998)

[Masataka 03] Tokumaru, M., Muranaka, N., Imanishi, S. : Virtual Stylist Project -Examination of Adapting Clothing Search System to user'sSubjectivity with Inteactive Genetic Algorithm-, Congress on volutionary Computation PROCEEDINGS, Vol. 2, pp. 1036-1043 (2003)

[加藤 97] 加藤直孝, 中条雅庸, 國藤進 : 合意生成プロセスを重視 したグループ意思決定支援システムの開発, 情報処理学会論文 誌, Vol. 38, No. 12, pp. 2629-2639 (1997)

[加藤 98] 加藤直孝, 國藤進 : 異なる評価構造を持つ参加者間の 合意形成支援法の提案と実装, 情報処理学会論文誌, Vol. 39, No. 10, pp. 2927-2936 (1998)

[角 02] 角 薰, 溝口理一郎 : オントロジー工学と HCI を融合し た協調型合意形成支援システム, 人工知能学会人工知能基礎論
研究会資料, Vol. 49, pp. 19-24 (2002)

[久保 00] 久保田直行, 渡邊和裕, 小島史男 : 人間共存型ロボット の軌道生成のための対話型遺伝的アルゴリズム, 日本機械学会 論文集 C 編, Vol. 66, No. 647, pp. 2274-2279 (2000)

[高木 96] 高木英行, 大宅喜美子, 大崎美穂 : 対話型遺伝的アルゴ リズムのインタフェース改善手法の提案と評価, ファジイシステ ムシンポジウム, Vol. 12, pp. 513-516 (1996)

[高木 00] 高木英行, 䰻見達夫, 寺野隆雄 : インタラクティブ進化 計算, 遺伝的アルゴリズム 4 , 第 11 章, pp. 325-365, 朝倉書店 (2000)

[三木 01] 三木光範, 廣安知之, 畠中一幸, 吉田純一 : 並列分散遺 伝的アルゴリズムの有効性, 日本計算工学会論文集, Vol. 3, pp. 29-34 (2001)

[小野 99] 小野功, 佐藤浩, 小林重信: 単峰性正規分布交叉 UNDX を用いた実数值 GA による関数最適化, 人工知能学会誌, Vol. 14, No. 6, pp. 1146-1155 (1999)

[小林 00] 小林重順 : カラーイメージスケール改訂版, 講談社 (2000)

[青木 98] 青木研, 高木英行 : 対話型 GA による 3 次元 CG ライ ティングデザイン支援, 電子情報通信学会論文誌, Vol. J81-D-2, No. 7, pp. 1601-1608 (1998)

[中洲 03] 中洲俊信, N.P.Chandrasiri,, 苗村健, 原島博 : 対話型 遺伝的アルゴリズムを用いた似顔絵作成, 電子情報通信学会技 術研究報告, Vol. 102, No. 735, pp. 31-36 (2003)

[渡部 92] 渡部和雄, W.HOLSAPPLE, C., B.WHINSTON, A.: コンセンサスに基づくグループ意思決定支援方式, 情報処理学 会論文誌, Vol. 33, No. 6, pp. 836-845 (1992)

[南風 02] 南風原朝和 : 心理統計学の基礎 統合的理解のために, 有斐閣 (2002)

[和田 03] 和田洋貴, 堀井千夏, 佐藤宏介 : 色彩デザインのための 配色イメージ創発支援システム, 日本色彩学会誌, Vol. 27, No. 1, pp. 3-11 (2003)

〔担当委員 : 栗原 聡〕

2004 年 8 月 20 日 受理

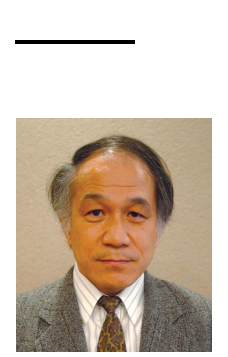

者 紹 介

\section{三木 光範(正会員)}

1978 年大阪市立大学大学院工学研究科博士課程修了, 工 学博士, 大阪市立大学工業研究所研究員, 金沢工業大学助 教授を経て, 1987 年大阪府立大学工学部航空宇宙工学科 助教授, 1994 年同志社大学工学部教授。進化的計算手法 と光の並列化，および知的なシステムの設計に関する研究 に従事. 著書は「工学問題を解決する適応化・知能化・最 適化法」(技法堂出版) 等多数. IEEE, 米国宇宙学会, 情 報処理学会, 人工知能学会, システム制御学会, 日本機械 学会, 計算工学会, 日本航空宇宙学会等会員. 超並列計算研究会代表, 経済産業 省産業技術審議会委員。

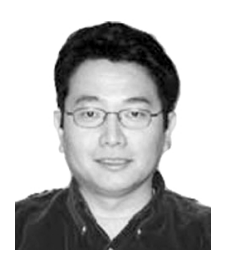

廣安 知之(正会員)

1997 年早稲田大学理工学研究科後期博士課程修了. 同年 早稲田大学工学部助手. 1998 年同志社大学工学部助手。 2001 年同大学専任講師. 2002 年テネシー大学客員研究員 を経て, 2003 年同志社大学工学部助教授、創発的計算, 進 化的計算, 最適設計, 並列処理などの研究に従事. IEEE 情報処理学会, 電気情報通信学会, 計測自動制御学会, 日 本機械学会, 超並列計算研究会, 日本計算工学会各会員.

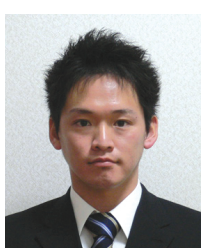

冨岡 弘志(学生会員)

1979 年生. 2003 年同志社大学工学部卒業. 2005 年同 志社大学大学院工学研究科修士課程修了. 同年 株式会社 電通国際情報サービス入社. 並列計算, 分散処理, 遺伝的 アルゴリズムに興味を持つ。 